\title{
P̈̈̈̈KIRJOITUS
}

\section{ASIANTUNTIJAT TUTKIMUKSEN JA KRITIIKIN KOHTEENA}

A siantuntijuus ja asiantuntijaksi kehittyminen ovat parin viime vuosikymmenen nopeimmin kasvaneita tutkimusalueita kasvatus- ja aikuiskasvatustieteessä. Tutkimusinnostukseen on vahvasti vaikuttanut neurotieteiden menetelmien kehittyminen. "Huippuasiantuntijoiden" kognitiivisia ja neuraalisia prosesseja tutkimalla on koetettu paikantaa poikkeuksellisen henkisen suorituskyvyn fysiologisia ilmenemismuotoja. Tavoitteena on ymmärtää paremmin asiantuntijoiden ongelmanratkaisukykyjä ja tiedostamattomasti tapahtuvia kognitiivisia prosesseja. Asiantuntijuuden kehittyminen on tietynlaisten tottumusten kehittymistä ja juurtumista yksilön toimintatapoihin. Asiantuntijalla tottumuksiin yhdistyvät kontekstintaju ja tilanneherkkyys, "pelisilmä".

AsiantuntijuUdelle on kysyntää. Se on yksi vastaus maailman monimutkaistumiseen, monin tavoin verkottuneen "riskiyhteiskunnan" haavoittuvuuteen. Päätöksenteko halutaan perustaa asiantuntijoiden tuottamaan näyttöön. On kuitenkin käynyt yhä ilmeisemmäksi, että yhteiskunnallisten ongelmien ratkaisemiseen tuotettu asiantuntijatieto on aina eräänlaista näkökulmatietoa. Asiantuntijallakaan ei ole tarjota "puhtaita faktoja". Joskus päätöksenteossa asiantuntijatietoa myös käytetään tarkoitushakuisesti pyhittä- mään poliittisia päämääriä ja ryhmäkohtaisia intressejä palvelevia toimenpiteitä. Omalla kapealla tontillaan asioihin syventynyt asiantuntija on tietoa ja ratkaisuja tuottaessaan tullut vedetyksi osaksi politiikan ja vallankäytön verkostoa. Kun politiikassa tehdään niin sanottuja vaikeita päätöksiä, virkakoneistossa työskentelevät asiantuntijat työnnetään eturintamaan torpedoimaan kansalaisten taholta tuleva kritiikki mahdottomana ja "nykytilanteeseen sopimattomana".

AsiantuntiJuUden tUTKIMUS ei rajoitu pelkästään asiantuntijaan yksilönä. Tässä numerossa Kai Hakkarainen, Jiri Lallimo ja Seppo Toikka muotoilevat kollektiivisen asiantuntijuuden näkökulmaa, jossa "yhdistyvät asiantuntijuuden yksilölliset sekä yhteisölliset ja verkostoituneet ulottuvuudet, sosiaalisen ja materiaalisen yhteenkietoutuminen sekä pyrkimys uutta tietoa ja käytäntöjä luovaan toimintaan." Niin kutsuttu kristallisoitunut tietämys ei synny asiantuntijoiden päässä. Se omaksutaan ja sisäistetään kulttuurisesti ja historiallisesti kehittyneissä asiantuntijakulttuureissa osallistumisen kautta.

Asiantuntijuus jalostuu työyhteisöjen jaetuissa käytännöissä, joissa yksilökohtaiset, sosiaaliset ja materiaaliset tekijät yhdistyvät. Organisaation "kollektiivisen älykkyyden" materiaalisuutta ovat esimerkiksi yhteisön tietoartefaktit, jotka kantavat tietämystä uusille asiantuntijayksilöille. 
Musiikkipedagogi Niina Sapattinen tarkastelee asiantuntijuuden kehittymistä erittäin mielenkiintoisessa ympäristössä, orkesterin johtamisessa. Meille maallikoille kapellimestarien työ on kuin toinen maailma, johon Sapattinen avaa antropologisen ikkunan. Kapellimestarin asiantuntijuuden rakentumisessa alakohtaiset yksilölliset taidot ovat eittämättä tärkeitä, mutta muiden ihmisten rooli on niin ikään merkittävä. Sosiaalisessa näkökulmassa asiantuntijuus näyttäytyy yhteisön ominaisuutena. Asiantuntija yksilönä kuuluu aina johonkin sosiaaliseen yhteisöön ja kulttuuriin, ja asiantuntijaksi voi oppia ilman muodollista koulutustakin, osallistumalla käytäntöihin.

Myös ympäristö ja välineet ovat olennainen osa asiantuntijuutta, kuten taitoja yleisemminkin. Asiantuntijuuden kehittymiselle on tyypillistä toimiminen kompetenssien ylärajoilla. Kehittymisessä näitä kompetenssin rajoja ikään kuin työnnetään jatkuvasti tuonnemmaksi. Mutta kehittyminen edellyttää kiinnostusta työn kohteeseen ja sitoutumista ongelmanratkaisuun. Tekijän täytyy tuntea asia omakseen. Usein työ onkin asiantuntijalle intohimon kohde. Välinpitämättömyys työtä kohtaan on huono lähtökohta asiantuntijuuden kehittymiselle.

Asiantuntijat USEIN myös haluavat laajentaa asiantuntemuksensa sovellusaluetta. He haluavat vallata uusia kohteita, joissa kokeilla ja syventää osaamistaan. Asiantuntijan pitää nykyään yhä useammin aktiivisesti hankkia työ itselleen, toistuvasti kerta toisensa jälkeen. Yrittäjämäiset työtilaisuudet ovat lisääntyneet useilla sektoreilla. Nyttemmin sosiaalipoliittinen asiantuntijuus, auttaminen ja sosiaaliset interventiot ovat entistä useammin projektimuotoisia. Nykyinen julkishallintoajattelu korostaa keskusvallan hajauttamista, kilpailua, julkishallinnon tehtävien ulkoistamista ja sisäistä markkinoistamista. Ajattelu konkretisoituu kasvavana yrittäjämäisesti toimivien ammattiauttajien joukkona, joka on erikoistunut eri tavoin ongelmallisiksi diagnosoitujen ryhmien hoitamiseen ja tarpeiden tyydyttämiseen.

KRISTIINA BRUNILA käsittelee artikkelissaan yhdenlaisen asiantuntijatiedon soveltamista syrjäytymisvaarassa oleville nuorille aikuisille tarkoitetussa koulutuksessa. Kyse on meillä vähemmän puhutusta, mutta maailmalla leviävästä ilmiöstä, jota voidaan luonnehtia koulutuksen terapoitumiseksi. Mitä erilaisimmista syistä yhteiskunnan rattailta pudonneiden ongelmiin tartutaan terapeuttisella otteella, joka hakee legitimaationsa asiantuntijan auktoriteetista. Terapeuttinen kieli kääntää yhteiskunnallisperäiset ongelmat puheeksi sairauksista, riippuvuuksista, ahdistuksista, haavoittuvuudesta, hauraasta identiteetistä ja toimintahäiriöistä. Myös esimerkiksi Aikuiskasvatuksen Tutkimusseuran 70-vuotisjuhlassa puhunut Kathryn Ecclestone on varoittanut terapisoitumisen yksilöön käyvistä seurauksista: perimmäiseltä luonteeltaan yhteiskunnan rakenteisiin palautuvat ongelmat yksilöllistyvät, ja yksilöt saattavat itsekin omaksua "sairaan", "heikon" tai muuten marginaalin roolin. Aletaanko syrjäytyminen ymmärtää ongelmana, joka voidaan ratkaista emotionaalisella tasolla ja terapeuttisella koulutuksella? Asiantuntijavaltaan ja sen saamiin muotoihin ei kannata suhtautua huolettoman kritiikittömästi.

Heikki Silvennoinen 